\title{
Metal-Organic Frameworks as Adsorbents for Hydrogen Purification and Precombustion Carbon Dioxide Capture
}

\author{
Zoey R. Herm, ${ }^{\dagger}$ Joseph A. Swisher, ${ }^{\ddagger}$ Berend Smit, ${ }^{+, \neq}$Rajamani Krishna, ${ }^{\S}$ and Jeffrey R. Long ${ }^{*,+}$ \\ ${ }^{\dagger}$ Department of Chemistry and ${ }^{\ddagger}$ Department of Chemical and Biomolecular Engineering, University of California, Berkeley, \\ California 94720-1460, United States \\ ${ }^{\S}$ Van't Hoff Institute for Molecular Sciences, University of Amsterdam, Science Park 904, 1098 XH Amsterdam, The Netherlands
}

Supporting Information

\begin{abstract}
Selected metal-organic frameworks exhibiting representative properties-high surface area, structural flexibility, or the presence of open metal cation sites-were tested for utility in the separation of $\mathrm{CO}_{2}$ from $\mathrm{H}_{2}$ via pressure swing adsorption. Single-component $\mathrm{CO}_{2}$ and $\mathrm{H}_{2}$ adsorption isotherms were measured at $313 \mathrm{~K}$ and pressures up to $40 \mathrm{bar}$ for $\mathrm{Zn}_{4} \mathrm{O}(\mathrm{BTB})_{2}$ (MOF-177, $\mathrm{BTB}^{3-}=1,3,5$-benzenetribenzoate), $\mathrm{Be}_{12}(\mathrm{OH})_{12}(\mathrm{BTB})_{4}(\mathrm{Be}-\mathrm{BTB}), \mathrm{Co}(\mathrm{BDP})\left(\mathrm{BDP}^{2-}=\right.$ 1,4-benzenedipyrazolate), $\mathrm{H}_{3}\left[\left(\mathrm{Cu}_{4} \mathrm{Cl}\right)_{3}(\mathrm{BTTri})_{8}\right] \quad$ (Cu$\mathrm{BTTri} \mathrm{BTTri}^{3-}=1,3,5$-benzenetristriazolate), and $\mathrm{Mg}_{2^{-}}$ (dobdc) (dobdc ${ }^{4-}=1,4$-dioxido-2,5-benzenedicarboxylate). Ideal adsorbed solution theory was used to estimate realistic isotherms for the $80: 20$ and $60: 40 \mathrm{H}_{2} / \mathrm{CO}_{2}$ gas mixtures relevant to $\mathrm{H}_{2}$ purification and precombustion $\mathrm{CO}_{2}$ capture, respectively. In the former case, the results afford $\mathrm{CO}_{2} / \mathrm{H}_{2}$ selectivities between 2 and 860 and mixed-gas working capacities, assuming a 1 bar purge pressure, as high as $8.6 \mathrm{~mol} / \mathrm{kg}$ and $7.4 \mathrm{~mol} / \mathrm{L}$. In particular, metal-organic frameworks with a high concentration of exposed metal cation sites, $\mathrm{Mg}_{2}$ (dobdc) and $\mathrm{Cu}$-BTTri, offer significant improvements over commonly used adsorbents, indicating the promise of such materials for applications in $\mathrm{CO}_{2} / \mathrm{H}_{2}$ separations.
\end{abstract}

\footnotetext{
Coal is an abundant resource that is heavily relied upon for global energy, and therefore emission-free coal-fired power plants are a necessary near-term component of a clean energy future. ${ }^{1}$ Integrated gasification and combined cycle (IGCC) systems equipped with precombustion $\mathrm{CO}_{2}$ capture, wherein $\mathrm{CO}_{2}$ is separated from $\mathrm{H}_{2}$ and sequestered, are promising in this regard. ${ }^{2}$ The technology for separating $\mathrm{H}_{2}$ and $\mathrm{CO}_{2}$ is already well-developed due to the tremendous scale of $\mathrm{H}_{2}$ production ( 50 million tons per year worldwide) and is primarily accomplished using pressureswing adsorption (PSA). ${ }^{3}$ Here, porous zeolites or activated carbons selectively and reversibly adsorb impurities in the presence of $\mathrm{H}_{2}$ at high pressures. Methods for altering the current PSA specifications to meet the needs of precombustion $\mathrm{CO}_{2}$ capture in an IGCC system are being explored, ${ }^{4}$ although vast improvements in $\mathrm{CO}_{2} / \mathrm{H}_{2}$ separations must be made to render this strategy economically viable. ${ }^{2 \mathrm{f}}$ Regardless, optimizing the efficiency of adsorptive $\mathrm{H}_{2}$ purification in industry is also of crucial importance to minimizing energy usage, ${ }^{5}$ since, at current production rates, which are steadily rising, a $10 \%$ increase in the efficiency of the process could save the
}

energy output of approximately 18 average US coal-fired power plants. ${ }^{6}$

Much of the energy input for a PSA system is used in mass transport of the gas and regeneration of the adsorbents, and as a result improving adsorbent selectivity and the capacity for $\mathrm{CO}_{2}$ would increase efficiency. ${ }^{3 \mathrm{f}}$ Extensive experimental ${ }^{7}$ and theoretical ${ }^{8}$ investigations suggest that further optimization of zeolites and activated carbons will yield only modest improvements in $\mathrm{CO}_{2} / \mathrm{H}_{2}$ separation performance. Thus, there is a need for new types of adsorbents with the potential for displaying significantly improved $\mathrm{CO}_{2}$ capacity and selectivity.

Microporous metal-organic frameworks offer significant promise in this regard but have yet to be experimentally investigated for the separation of $\mathrm{CO}_{2}$ from $\mathrm{H}_{2}$. These materials exhibit record internal surface areas and, as a result, a tremendous $\mathrm{CO}_{2}$ storage capacity ${ }^{9}$ at the pressures relevant for a $\mathrm{CO}_{2} / \mathrm{H}_{2}$ separation (ca. 5-40 bar). ${ }^{3 a, f, 6 a}$ Further, the high adsorbent surface area could enhance the selectivity for adsorption of $\mathrm{CO}_{2}$ over $\mathrm{H}_{2}$, since $\mathrm{H}_{2}$ packs more efficiently than $\mathrm{CO}_{2}$ due to its smaller size. ${ }^{10}$ Moreover, the ability to adjust the nature of the surfaces within these materials could potentially be exploited to increase the strength of the interaction with $\mathrm{CO}_{2}{ }^{11}$ and has already spurred investigations into their uses in other industrially relevant gas separations, such as $\mathrm{CO}_{2} /$ $\mathrm{N}_{2}{ }^{12} \mathrm{CO}_{2} / \mathrm{CH}_{4}{ }^{12 \mathrm{a}, 13}$ and $\mathrm{O}_{2} / \mathrm{N}_{2}$ separations. ${ }^{14}$

Despite the recent interest in high-pressure, fixed-bed separation applications using metal-organic frameworks as the adsorbent, ${ }^{12 a}$ their study for $\mathrm{CO}_{2} / \mathrm{H}_{2}$ separations has thus far been limited to theoretical investigations, which have predicted excellent selectivities. $^{10,15}$ Herein, we report the first experimental study of the utility of metal-organic frameworks for high-pressure $\mathrm{CO}_{2} / \mathrm{H}_{2}$ separation by PSA. ${ }^{16}$ We consider single-component $\mathrm{CO}_{2}$ and $\mathrm{H}_{2}$ adsorption isotherms as an initial indicator of effectiveness and further adopt a complementary theoretical model for the prediction of the performance of each material under realistic mixed gas conditions.

The compounds $\mathrm{Zn}_{4} \mathrm{O}(\mathrm{BTB})_{2}$ (MOF-177, $\mathrm{BTB}^{3-}=1,3,5-$ benzenetribenzoate $)^{17}$ and $\mathrm{Be}_{12}(\mathrm{OH})_{12}(\mathrm{BTB})_{4}(\mathrm{Be}-\mathrm{BTB})^{18}$ were chosen as representative of metal-organic frameworks exhibiting a high surface area and a rigid framework structure. As a flexible framework, $\mathrm{Co}(\mathrm{BDP})\left(\mathrm{BDP}^{2-}=1\right.$,4-benzenedipyrazolate $)$ was selected owing to its high surface area relative to most compounds of this type ${ }^{19}$ Finally, $\mathrm{H}_{3}\left[\left(\mathrm{Cu}_{4} \mathrm{Cl}\right)_{3}(\text { BTTri })_{8}\right]\left(\mathrm{Cu}-\mathrm{BTTri}, \mathrm{BTTri}{ }^{3-}=\right.$ 1,3,5-benzenetristriazolate) ${ }^{12 c}$ and $\mathrm{Mg}_{2}$ (dobdc) (dobdc ${ }^{4-}=1,4$ dioxido-2,5-benzenedicarboxylate) ${ }^{11 a}$ were chosen as prototypical of the broad class of metal-organic frameworks that possess surfaces

Received: December 18, 2010

Published: March 25, 2011 


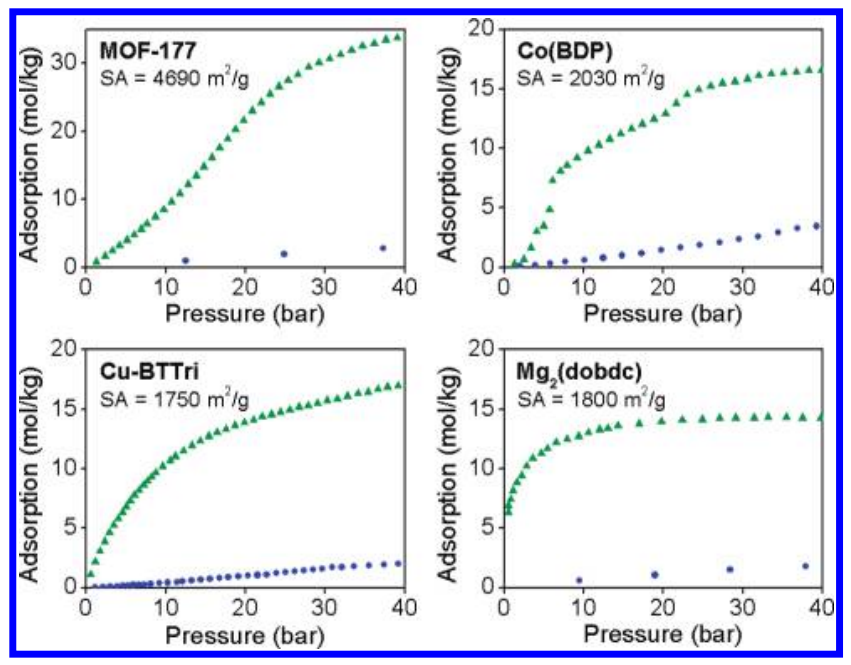

Figure 1. Absolute adsorption isotherms for $\mathrm{CO}_{2}$ (green triangles) and $\mathrm{H}_{2}$ (blue circles) in MOF-177, $\mathrm{Co}(\mathrm{BDP}), \mathrm{Cu}-\mathrm{BTT}$ ri, and $\mathrm{Mg}_{2}$ (dobdc) at $313 \mathrm{~K}$. The BET surface area (SA) obtained for each framework is given.

coated with exposed metal cations. All five compounds were synthesized and activated as previously reported, and their BET surface areas (see Figure 1) were determined from $\mathrm{N}_{2}$ adsorption isotherms collected at $77 \mathrm{~K}$ (see Table S7 for Langmuir surface areas and pore volumes).

Figure 1 shows the single-component $\mathrm{CO}_{2}$ and $\mathrm{H}_{2}$ adsorption isotherms recorded at $313 \mathrm{~K}$ for MOF-177, Co(BDP), Cu-BTTri, and $\mathrm{Mg}_{2}$ (dobdc). Data for Be-BTB, which are similar to the results obtained for MOF-177, are presented in Figure S8. As might be expected, the $\mathrm{CO}_{2}$ adsorption capacity scales roughly with surface area and is much higher than the corresponding adsorption capacity for $\mathrm{H}_{2}$ due to the higher polarizability and quadrupole moment of the $\mathrm{CO}_{2}$ molecule. The $\mathrm{CO}_{2}$ adsorption capacity also scales qualitatively with the accessible pore volumes of 1.59, 0.93, 0.713, and $0.573 \mathrm{~cm}^{3} / \mathrm{g}$ for MOF-177, Co(BDP), Cu-BTTri, and $\mathrm{Mg}_{2^{-}}$ (dobdc), respectively.

Notably, Cu-BTTri and $\mathrm{Mg}_{2}$ (dobdc) exhibit high $\mathrm{CO}_{2}$ adsorption (particularly at low pressures) relative to their surface areas due to the additional polarizing influence of the open metal cation sites decorating the framework surfaces. Contrasting with these results, the step-like features in the $\mathrm{CO}_{2}$ isotherm for $\mathrm{Co}(\mathrm{BDP})$ are likely associated with a gate-opening phenomenon arising from the flexibility of the framework structure. ${ }^{20}$

In order to probe the performance of the materials, ideal adsorbed solution theory (IAST) was employed to estimate mixed-gas adsorption behavior. ${ }^{21}$ The accuracy of IAST for estimating component loadings for adsorption of a wide variety of binary mixtures in zeolites has been established with the aid of Configurational-Bias Monte Carlo (CBMC) simulations. ${ }^{22}$ Specifically, it has been previously been applied to the separation of $\mathrm{CO}_{2}$ from $\mathrm{H}_{2}$ within metal-organic frameworks ${ }^{15 a, c, e}$ and other porous solids. ${ }^{7 a, f, 8 a, d}$ Further, CBMC simulations data provide evidence of the validity of its use for estimation of $\mathrm{CO}_{2} / \mathrm{H}_{2}$ equilibria in metal-organic frameworks and are presented in the Supporting Information.

Figure 2 shows the selectivities for $\mathrm{CO}_{2}$ over $\mathrm{H}_{2}$ under an 80:20 $\mathrm{H}_{2} / \mathrm{CO}_{2}$ gas mixture relevant to $\mathrm{H}_{2}$ purification ${ }^{3}$ calculated for the metal-organic frameworks using the single-component gas sorption isotherms. Significantly, the two frameworks with exposed metal cation sites, Cu-BTTri and $\mathrm{Mg}_{2}$ (dobdc), display by far the highest

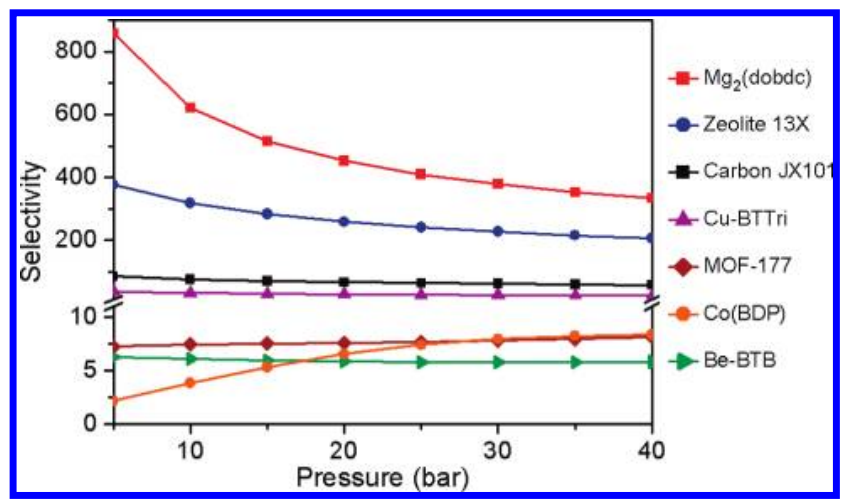

Figure 2. IAST $\mathrm{CO}_{2} / \mathrm{H}_{2}$ selectivities for a $80: 20 \mathrm{H}_{2} / \mathrm{CO}_{2}$ mixture at $313 \mathrm{~K}$, as calculated from gas sorption isotherms collected for the metal-organic frameworks MOF-177, Be-BTB, Co(BDP), Cu-BTTri, and $\mathrm{Mg}_{2}(\mathrm{dobdc})$, activated carbon $\mathrm{JX} 101,{ }^{25}$ and zeolite $13 \mathrm{X}^{26}$

selectivities, presumably owing to the greater polarizability of $\mathrm{CO}_{2}$ versus $\mathrm{H}_{2}$. At saturation, $\mathrm{Mg}_{2}$ (dobdc) adsorbs $1.8 \mathrm{CO}_{2}$ molecules per $\mathrm{Mg}$ and $\mathrm{Cu}-\mathrm{BTT}$ Tri adsorbs $4.5 \mathrm{CO}_{2}$ molecules per $\mathrm{Cu}$ (see Figures $\mathrm{S} 9$ and $\mathrm{S} 10$ ). These values, and particularly the steep rise in the lower pressure data for the former case, suggest that the observed selectivity can preliminarily be ascribed to interactions with the open metal cation sites. Indeed, the enhanced interaction of guest gas molecules, and specifically $\mathrm{CO}_{2}$, in porous materials with coordinatively unsaturated metal sites is well-established. ${ }^{9 a, b, 11 a, 13 d, 23}$

With a greater concentration of cationic sites exposed on its surfaces, $\mathrm{Mg}_{2}$ (dobdc) shows the best performance, exhibiting a selectivity that gradually decreases from 859 at 5 bar to 305 at 40 bar. We note that this material has also previously been shown to exhibit a high $\mathrm{CO}_{2} / \mathrm{N}_{2}$ and $\mathrm{CO}_{2} / \mathrm{CH}_{4}$ selectivity. ${ }^{11 a, 12 \mathrm{~d}}$

The other metal-organic frameworks, MOF-177, Be-BTB, and $\mathrm{Co}(\mathrm{BDP})$, all show drastically lower selectivities of less than 10 . The particularly poor performance of Be-BTB is likely associated with its unusually high $\mathrm{H}_{2}$ uptake, as previously reported at $298 \mathrm{~K}$, and attributed to the dimensions of the rings comprising its structure. ${ }^{18}$ We note that, although flexible frameworks such as $\mathrm{Co}(\mathrm{BDP})$ are sometimes touted as good separation materials based on singlecomponent isotherms, cooperative effects, in which one gas can open the pores and facilitate admission of the other, may invalidate these claims (and indeed application of IAST).

For comparison, $\mathrm{CO}_{2}$ and $\mathrm{H}_{2}$ isotherm data for common PSA adsorbents, ${ }^{3 e, f, 6 a}$ zeolite $5 \mathrm{~A}^{24}$ and two activated carbons, ${ }^{24,25}$ were taken from the literature and treated similarly using IAST. Due to the variability in activated carbons, both $\mathrm{JX} 01^{25}$ and $\mathrm{BPL}^{24}$ were considered in an effort to broaden the scope of the comparison. Data for zeolite $13 \mathrm{X}^{26}$ were also included, since this material has recently been shown to outperform zeolite $5 \mathrm{~A}$ in terms of $\mathrm{CO}_{2}$ capacity ${ }^{27}$ and breakthrough measurements. ${ }^{28}$ Zeolite $13 \mathrm{X}$ selectivity values are depicted in Figure 2 at $313 \mathrm{~K}$ (determined from interpolating adsorption data at 303 and $323 \mathrm{~K}$ ), and $\mathrm{Mg}_{2}$ (dobdc) outperforms zeolite $13 \mathrm{X}$ at all pressures. Selectivities for zeolite $5 \mathrm{~A}$ at $303 \mathrm{~K}$ (which can be assumed to decrease at $313 \mathrm{~K}$ ) are similar to those of $\mathrm{Mg}_{2}$ (dobdc), but with higher values at low pressures and slightly lower values at high pressures (see Figure S14). Thus, in terms of selectivity, $\mathrm{Mg}_{2}$ (dobdc) can be expected to perform the separation of $\mathrm{CO}_{2}$ from $\mathrm{H}_{2}$ at least as well as any known adsorbent under the conditions assessed. The selectivity values for a $60: 40 \mathrm{H}_{2} / \mathrm{CO}_{2}$ mixture relevant to precombustion $\mathrm{CO}_{2}$ capture ${ }^{2 \mathrm{f}}$ are shown in Figure $\mathrm{S} 15$ and follow approximately the same hierarchy. 


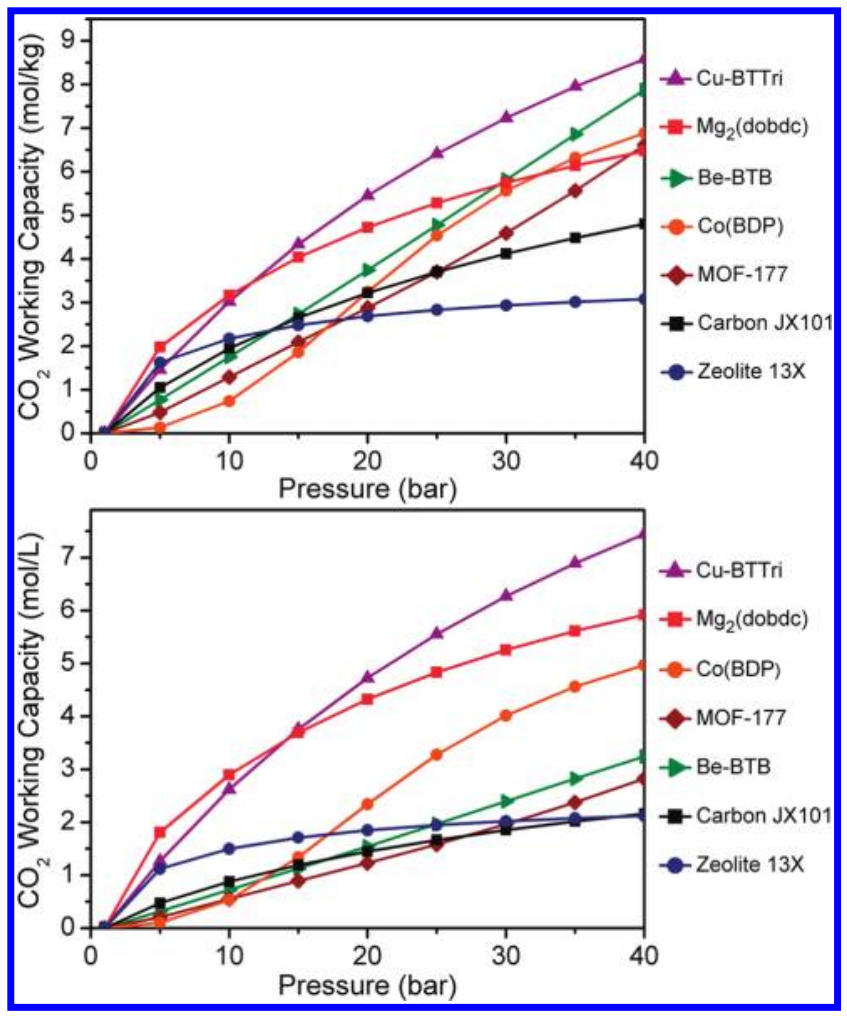

Figure 3. IAST-calculated gravimetric (top) and volumetric (bottom) $\mathrm{CO}_{2}$ working capacities for an $80: 20 \mathrm{H}_{2} / \mathrm{CO}_{2}$ mixture at $313 \mathrm{~K}$ for the metal-organic frameworks MOF-177, Be-BTB, Co(BDP), Cu-BTTri, and $\mathrm{Mg}_{2}$ (dobdc), the activated Carbon JX101 ${ }^{23}$ and zeolite $13 \mathrm{X}^{24}$

Due to the nature of PSA purification, the working capacity - the difference between the capacity at the high intake pressure and at the lower purge pressure-is a critical metric for evaluating adsorbents. ${ }^{3 \mathrm{e}, 29}$ The $\mathrm{CO}_{2}$ working capacities for the metal-organic frameworks under an 80:20 $\mathrm{H}_{2} / \mathrm{CO}_{2}$ mixture and assuming a purge pressure of 1 bar were calculated using IAST and compared to the values obtained for the zeolites and activated carbons (see Figure 3). While gravimetric capacities (moles of $\mathrm{CO}_{2}$ adsorbed per $\mathrm{kg}$ of adsorbent) are normally reported when evaluating materials for a $\mathrm{CO}_{2} / \mathrm{H}_{2}$ separation, the volumetric working capacities (moles of $\mathrm{CO}_{2}$ adsorbed per $\mathrm{L}$ of adsorbent) were also calculated, since both factors are critical in designing a PSA separation process. ${ }^{6 a}$ Here, the true advantage of utilizing metal-organic frameworks comes to the fore. Owing to its greater specific surface area and larger pore sizes, $\mathrm{Mg}_{2}$ (dobdc) outperforms the zeolites by a considerable margin, with working capacities climbing to values of $6.4 \mathrm{~mol} / \mathrm{kg}$ and $5.9 \mathrm{~mol} / \mathrm{L}$ at 40 bar. Thus, at higher pressures, use of $\mathrm{Mg}_{2}$ (dobdc) in place of zeolite 13X could reduce the mass of adsorbent needed by a factor of 2.0 and the volume needed by a factor of 2.7. For a $60: 40 \mathrm{H}_{2} / \mathrm{CO}_{2}$ mixture, the working capacities of metal-organic frameworks offer similar benefits (see Figures S18 and S19). Here, however, due to the higher partial pressure of $\mathrm{CO}_{2}$, the relative steepness of the $\mathrm{CO}_{2}$ isotherm for $\mathrm{Mg}_{2}$ (dobdc) is less of an advantage, resulting in working capacities that are less than those of $\mathrm{Cu}$-BTTri.

In this investigation, we have shown that metal-organic frameworks containing strongly adsorbing sites are excellent candidates for $\mathrm{CO}_{2} / \mathrm{H}_{2}$ separations. Interestingly, the high surface areas and concomitant extraordinary $\mathrm{CO}_{2}$ uptake of many metal-organic frameworks do not necessarily make them ideal for such separations.
This conclusion could also potentially apply to other separations within metal-organic frameworks. Industrially, adsorbents for this separation are tailored and optimized for each specific PSA system, ${ }^{\text {a }}$ and therefore the equilibrium adsorption data presented here provide an initial step toward improving the efficiency of the process. In order to validate the efficacy of metal-organic frameworks, however, additional experiments are still needed, such as investigating $\mathrm{CO}_{2}$ desorption by purge. ${ }^{30}$ This regeneration is not expected to stand in the way of their use, however, since the isosteric heats of $\mathrm{CO}_{2}$ adsorption in $\mathrm{Mg}_{2}$ (dobdc) $(47 \mathrm{~kJ} / \mathrm{mol})^{11 \mathrm{a}}$ and $\mathrm{Cu}-$ BTTri $(21 \mathrm{~kJ} / \mathrm{mol})^{12 \mathrm{c}}$ are quite similar to those of the currently employed zeolite $5 \mathrm{~A}(40 \mathrm{~kJ} / \mathrm{mol})$ and activated carbon $(23 \mathrm{~kJ} /$ $\mathrm{mol})^{3 \mathrm{f}}$ (see Figure S20). Ultimately, the successful implementation of such new adsorbents could both reduce the substantial energy cost of hydrogen purification and eliminate $\mathrm{CO}_{2}$ emissions in the generation of electricity from coal. Along these lines, future work will probe whether metal-organic frameworks with good thermal and hydrolytic stability might even be suitable for the in situ separation of $\mathrm{CO}_{2}$ from $\mathrm{H}_{2}$ during sorption-enhanced water-gas shift reactions. ${ }^{31}$

\section{ASSOCIATED CONTENT}

Supporting Information. Complete experimental details, measured experimental data, data selected from the literature for comparison, methodology for conversion of adsorption excess loadings to absolute loadings, dual-site Langmuir-Freundlich fits of pure component isotherms, along with IAST calculations of component loadings in mixed gases, adsorption selectivities, and working capacities. This material is available free of charge via the Internet at http://pubs.acs.org.

\section{AUTHOR INFORMATION}

\section{Corresponding Author}

jrlong@berkeley.edu

\section{ACKNOWLEDGMENT}

This research was funded through the Center for Gas Separations Relevant to Clean Energy Technologies, an Energy Frontier Research Center funded by the U.S. Department of Energy, Office of Science, Office of Basic Energy Sciences under Award No. DE-SC0001015. We thank Dr. S. Karim and Dr. K. Gross for experimental assistance.

\section{REFERENCES}

(1) Chu, S. Science 2009, 325, 1599.

(2) (a) Schütz, M.; Daun, M.; Weinspach, P.-M.; Drumbeck, M.; Hein, K. R. G. Eneroy Convers. Manage. 1992, 33, 357. (b) Hendriks, C. A.; Blok, K. Energy Convers. Manage. 1992, 33, 387. (c) OrdoricaGarcia, G.; Douglas, P.; Croiset, E.; Zheng, L. Energy Convers. Manage. 2006, 47, 2250. (d) Descamps, C.; Bouallou, C.; Kanniche, M. Energy 2008, 33, 874. (e) Kanniche, M.; Gros-Bonnivard, R.; Jaud, P.; ValleMarcos, J.; Amann, J.-M.; Bouallou, C. Appl. Therm. Eng. 2010, 30, 53. (f) US Department of Energy National Energy Technology Laboratory. Carbon Sequestration FAQ Information Portal. http://www.netl.doe. gov/technologies/carbon_seq/FAQs/tech-status.html\#PreCombustion (accessed December 1, 2010).

(3) (a) Sircar, S.; Golden, T. C. Sep. Sci. Technol. 2000, 35, 667. (b) Sircar, S. Ind. Eng. Chem. Res. 2002, 41, 1389. (c) Ockwig, N. W; Nenoff, T. M. Chem. Rev. 2007, 107, 4078. (d) Ritter, J. A.; Ebner, A. D. Sep. Sci. Technol. 2007, 42, 1123. (e) Yang, S.-I.; Choi, D.-Y.; Jang, S.-C.; Kim, S.H.; Choi, D.-K. Adsorption 2008, 14, 583.(f) Sircar, S.; Golden, T. C. 
Hydrogen and Syngas Production and Purification Technologies; Liu, K., Song, C., Subramani, V., Eds.; Wiley-AIChE: Hoboken, NJ, 2010; pp 414-450.

(4) Agarwal, A.; Biegler, L. T.; Zitney, S. E. Ind. Eng. Chem. Res. 2010, 49, 5066.

(5) (a) Pant, K. K., Gupta, R. B. Hydrogen Fuel: Production, Transport and Storage; Gupta, R., Ed.; CRC Press: Boca Raton, FL, 2004. (b) US Department of Energy, Materials for Separation Technologies: Energy and Emission Reduction Opportunities. http://www1.eere.energy.gov/industry/imf/analysis.html (accessed October 24, 2010).

(6) (a) Damle, A. Hydrogen Fuel: Production, Transport and Storage; Gupta, R., Ed.; CRC Press: Boca Raton, FL, 2004. (b) US Energy Information Administration, http://www.eia.doe.gov/cneaf/electricity/epa/epat1p2.html (accessed October 24, 2010).

(7) (a) Hwang, K. S.; Gong, S. Y.; Lee, W. K. Korean J. Chem. Eng. 1991, 8, 148. (b) Kim, W.-G.; Yang, J.; Han, S.; Cho, C.; Lee, C.-H.; Lee, H. Korean J. Chem. Eng. 1995, 12, 503. (c) Yang, J.; Lee, C.-H.; Chang, J.Y. Ind. Eng. Chem. Res. 1997, 36, 2789. (d) Wirawan, S. K.; Creaser, D. Sep. Purif. Technol. 2006, 52, 224. (e) Majlan, E. H.; Daud, W. R. W.; Iyuke, S. E.; Mohamad, A. B.; Kadhum, A. A. H.; Mohammad, A. W.; Takriff, M. S.; Bahaman, N. Int. I. Hvdrogen Energy 2009, 34, 2771. (f) Belmabkhout, Y.; Sayari, A. Chem. Eng. Sci. 2009, 64, 3729. (g) Lopes, F. V. S.; Grande, C. A.; Ribeiro, A. M.; Oliveira, E. L. G.; Loureiro, J. M.; Rodrigues, A. E. Ind. Eng. Chem. Res. 2009, 48, 3978. (h) Lopes, F. V. S.; Grande, C. A.; Ribeiro, A. M.; Loureiro, J. M.; Evaggelos, O.; Nikolakis, V.; Rodrigues, A. E. Sep. Sci. Technol. 2009, 44, 1045. (i) Lopes, F. V. S.; Grande, C. A.; Rodrigues, A. E. Chem. Eng. Sci. 2010, 66, 303.

(8) (a) Akten, E. D.; Siriwardane, R; Sholl, D. S. Energy Fuels 2003, 17, 977. (b) Cao, D.; Wu, J. Carbon 2005, 43, 1364. (c) Gallo, M.; Nenoff, T. M.; Mitchell, M. C. Fluid Phase Eauilib. 2006, 247, 135. (d) Jaschik, J.; Tañczyk, M.; Warmuziñski, K.; Jaschik, M. Chem. Proc. Eng. 2009, 30, 511. (e) Krishna, R.; van Baten, J. M. J. Membr. Sci. 2010, $360,323$.

(9) (a) Millward, A.; Yaghi, O. M. J. Am. Chem. Soc. 2005, 127, 17998. (b) Llewellyn, P. L.; Bourrelly, S.; Serre, C.; Vimont, A.; Daturi, M.; Hamon, L.; Weireld, G. D.; Chang, J.-S.; Hong, D.-Y.; Hwang, Y. K.; Jhung, S. H.; Férey, G. Langmuir 2008, 24, 7245. (c) Furukawa, H.; Ko, N.; Go, Y. B.; Aratani, N.; Choi, S. B.; Choi, E.; Yazaydin, A. Ö.; Snurr, R. Q.; O’Keeffe, M.; Kim, J.; Yaghi, O. M. Science 2010, 329, 424.

(10) (a) Yang, Q.; Xu, Q.; Liu, B.; Zhong, C.; Smit, B. Chin. J. Chem. Eng. 2009, 17, 781. (b) Jiang, J. AIChE J. 2009, 55, 2422.

(11) (a) Caskey, S. R.; Wong-Foy, A. G.; Matzger, A. J. J. Am. Chem. Soc. 2008, 130, 10870. (b) Liang, Z.; Marshall, M.; Chaffee, A. L. Energy Fuels 2009, 23, 2785.

(12) (a) Bastin, L.; Bárcia, P. S.; Hurtado, E. J.; Silva, J. A. C.; Rodrigues, A. E.; Chen, B. I. Phys. Chem. C 2008, 112, 1575. (b) Bae, Y. S.; Farha, O. K.; Hupp, J. T.; Snurr, R. Q. J. Mater. Chem. 2009, 19, 2131. (c) Demessence, A.; D’Alessandro, D.; Foo, M. L.; Long, J. R. I. Am. Chem. Soc. 2009, 131, 8784. (d) Dietzel, P. D. C.; Besikiotis, V.; Blom, R. I.Mater. Chem. 2009, 19, 7362.

(13) (a) Eddaoudi, M.; Kim, J.; Rosi, N.; Vodak, D.; Watcher, J.; O'Keeffe, M.; Yaghi, O. M. Science 2002, 295, 469. (b) Bourrelly, S.; Llewellyn, P. L.; Serre, C.; Millange, F.; Loiseau, T.; Férey, G. J. Am. Chem. Soc. 2005, 127, 13519. (c) Bae, Y.-S.; Mulfort, K. L.; Frost, H.; Ryan, P.; Punnathanam, S.; Broadbelt, L. J.; Hupp, J. T.; Snurr, R. Q. Langmuir 2008, 24, 8592. (d) Mu, B.; Li, F.; Walton, K. S. Chem. Commun. 2009, 2493. (e) Britt, D.; Furukawa, H.; Wang, B.; Glover, T. G.; Yaghi, O. M. Proc. Natl. Acad. Sci. U.S.A. 2009, 106, 20637.

(14) Murray, L. J.; Dinca, M.; Yano, J.; Chavan, S.; Bordiga, S.; Brown, C. M.; Long, J. R. I. Am. Chem. Soc. 2010, 132, 7856.

(15) (a) Yang, Q.; Zhong, C. J. Phys. Chem. B 2006, 110, 17776. (b) Babarao, R.; Jiang, J. I. Am. Chem. Soc. 2009, 131, 11417. (c) Liu, Y.; Liu, D.; Yang, Q.; Zhong, C.; Mi, J. Ind. Eng. Chem. Res. 2010, 49, 2902. (d) Babarao, R.; Eddaoudi, M.; Jiang, J. W. Langmuir 2010, 26, 11196. (e) Chen, Y.; Jiang, J. ChemSusChem 2010, 3, 982. (f) Wu, D.; Xu, Q.; Liu, D.; Zhong, C. L.Phvs. Chem. C 2010, 114, 16611. (g) Babarao, R.; Jiang, I. W. Ind. Eng. Chem. Res. 2011, 50, 62.
(16) While high-pressure $\mathrm{CO}_{2}$ and $\mathrm{H}_{2}$ adsorption isotherms have been reported previously for various metal-organic frameworks, including some of the ones studied here, to our knowledge they have never been investigated in relation to a realistic $\mathrm{H}_{2}$ purification separation. See for example: (a) Miller, S. R.; Wright, P. A.; Devic, T.; Serre, C.; Férey, G.; Llewellyn, P. L.; Denoyel, R.; Gaberova, L.; Filinchuk, Y. Langmuir 2009, 25, 3618. (b) Guo, H.; Zhu, G.; Hewitt, I. J.; Qui, S. J. Am. Chem. Soc. 2009, 131, 1646.

(17) Chae, H. K.; Siberio-Pérez, D. Y.; Kim, J.; Go, Y.; Eddaoudi, M.; Matzger, A. J.; O’Keefe, M.; Yaghi, O. M. Nature 2004, 427, 523.

(18) Sumida, K.; Hill, M. R.; Horike, S.; Dailly, A.; Long, J. R. J. Am. Chem. Soc. 2009, 131, 15120.

(19) Choi, H. J.; Dincă, M.; Long, J. R. J. Am. Chem. Soc. 2008, 130, 7848 .

(20) (a) Li, J.-R.; Kuppler, R. J.; Zhou, H.-C. Chem. Soc. Rev. 2009, 38, 1477. (b) Salles, F.; Maurin, G.; Serre, C.; Llewellyn, P. L.; Knöfel, C.; Choi, H. J.; Filinchuk, Y.; Oliviero, L.; Vimont, A.; Long, J. R.; Férey, G. I. Am. Chem. Soc. 2010, 132, 13782.

(21) Myers, A. L.; Prausnitz, J. M. AIChE J. 1965, 11, 121.

(22) (a) Krishna, R.; Calero, S.; Smit, B. Chem. Eng. J. 2002, 88, 81. (b) Krishna, R.; van Baten, J. M. Chem. Eng. I. 2007, 133, 121.

(23) (a) Prestipino, C.; Regli, L.; Vitillo, J. G.; Bonino, F.; Damin, A.; Lamberti, C.; Zecchina, A.; Solari, P. L.; Kongshaug, K. O.; Bordiga, S. Chem. Mater. 2006, 18, 1337. (b) Bordiga, S.; Regli, L.; Bonino, F.; Groppo, E.; Lamberti, C.; Xiao, B.; Wheatley, P. S.; Morris, R. E.; Zecchina, A. Phvs. Chem. Chem. Phvs. 2007, 9, 2676. (c) Yazaydin, A. Ö.; Snurr, R. Q.; Park, T.-H.; Koh, K.; Liu, J.; LeVan, M. D.; Benin, A. I.; Jakubczak, P.; Lanuza, M.; Galloway, D. B.; Low, J. J.; Willis, R. R. J. Am. Chem. Soc. 2009, 131, 18198. (d) Valenzano, L.; Civalleri, B.; Chavan, S.; Palomino, G. T.; Areán, C. O.; Bordiga, S. J. Phys. Chem. C 2010, $114,11185$.

(24) Sircar, S.; Golden, T. C.; Rao, M. B. Carbon 1996, 1, 1.

(25) Wu, J.; Zhou, L.; Sun, Y.; Su, W.; Zhou, Y. AIChE J. 2007, $53,1178$.

(26) Belmabkhout, Y.; Pirngruber, G.; Jolimaitre, E.; Methivier, A. Adsorption 2007, 13, 341.

(27) Bonenfant, D.; Kharoune, M.; Niquette, P.; Mimeault, M.; Hausler, R. Sci. Technol. Adv. Mater. 2008, 9, 1.

(28) Jadhav, P. D.; Rayalu, S. S.; Biniwale, R. B.; Devotta, S. Curr. Sci. 2007, 92, 724

(29) Ho, M. T.; Allinson, G. W.; Wiley, D. E. Ind. Eng. Chem. Res. 2008, 47, 4883.

(30) Sircar, S.; Golden, T. C. Ind. Eng. Chem. Res. 1995, 34, 2881.

(31) (a) Alpay, E.; Chatsiriwech, D.; Kershenbaum, L. S.; Hull, C. P.; Krikby, N. F. Chem. Eng. Sci. 1994, 49, 5845. (b) Hufton, J. R.; Mayorga, S.; Sircar, S. AIChE J. 1999, 45, 248. (c) Beaver, M. G.; Caram, H. S.; Sircar, S. Int. I. Hvdrogen Energy 2009, 34, 2972. 